\title{
Radicicol 6-oxime
}

National Cancer Institute

\section{Source}

National Cancer Institute. Radicicol 6-oxime. NCI Thesaurus. Code C1836.

A macrocyclic antifungal antibiotic, radicicol oxime derivative that binds and selectively depletes heat shock protein 90 (Hsp90) chaperone, a signaling molecule involved in signal transduction that plays a vital role in tumor cells growth. $(\mathrm{NCl})$ 